\title{
The return of liberal rabbinic education to Berlin
}

\section{Abraham Geiger College, Zacharias Frankel College and the School of Jewish Theology}

\author{
ELI REICH
}

DOI: $10.30752 /$ nj.84891

\begin{abstract}
Авstract - In Berlin two rabbinical seminaries, a Reform and a Conservative, have recently been established. The historical and intellectual roots of these institutions in the nineteenth century is sketched, and then contrasted with the present curriculum and the religious profile of the students. Some theological questions for the future of these projects conclude the article.
\end{abstract}

MY PAPER IS WRITTEN, to some extent, from the perspective of a participant-observer. On the one hand I received my education outside these institutions, but on the other hand I have now been teaching both at the School of Jewish Theology and at the Abraham Geiger College for the last four years, where I was also ordained. I received my undergraduate education in Israel (Bar-Ilan University), and my graduate education in Israel (Hebrew University) and the USA, both at 'Jewish' institutions (JTS, Brandeis University) and at the University of Chicago Divinity School. At Abraham Geiger College I teach Halakhah, and participate regularly in the Friday Night Kabbalat Shabbat Service and meal.

At the School of Jewish Theology I have taught courses on Mishnah, Midrash, Talmud, Liturgy, Maimonides, Zohar, Rav Nahman of Braslav and Abraham Isaac Kook. My students at the School of Jewish Theology include rabbinical students from both Abraham Geiger College and the Zacharias Frankel College (as well as many non-rabbinical students).
I start by briefly describing the two colleges and the school. From the present I turn back to the past, to look at the historical background. Finally I discuss some aspects of the colleges, and raise some questions about the future.

\section{In the present:}

\section{introducing the institutions}

The first class at Abraham Geiger College, a part of Potsdam University, started in 200I. Currently there are fifteen rabbinical and eight cantorial students. The Zacharias Frankel Rabbinical College opened its gates in 20I3, and is identified with Masorti Judaism, the denomination known in the USA as Conservative Judaism. Zacharias Frankel College currently has seven students. The two colleges offer their academic education at the School of Jewish Theology, where the curriculum is designed with rabbinical students in mind. The standard subjects taught are: Hebrew Bible (Tanakh), Talmud, Halakhah, rabbinic literature, liturgy, history and Jewish philosophy. The rabbinical students receive a BA and an MA in Jewish 
theology. Not only rabbinical students, however, study at the School of Jewish Theology, since it is open to any interested student. The rabbinical students receive their practical training at their respective colleges. In between the degrees students spend a year of study at the Conservative Yeshiva in Jerusalem. Here they immerse themselves in traditional text study, released from the constraints of the regular coursework of the university.

\section{The past: historical background}

The roots of the rabbinical colleges go back to mid-nineteenth-century Germany. As a result of the increasing emancipation of the Jews, the growing secularisation of Jewish life and the impact of Enlightenment thought, new interests emerged among the Jews. One was the demand to reform Jewish practices, to bring them more in line with contemporary culture and sensibilities. Sermons were expected not only to be in German, but also to resonate with refined culture and education (Bildung). The second interest was in the critical historical investigation of the past. Philology and historical research jointly gave birth to a new historical consciousness. Two developments emerged out of this new consciousness: the Wissenschaft des Judentums, i.e., the academic approach to the history of Judaism in all its cultural manifestations, and the concept of the liberal rabbi. Often these two tendencies were embodied in the same person. That is the case with the rabbis Abraham Geiger (1810-74) and Zacharias Frankel (I80I-75). A sign of this synthesis between Wissenschaft des Judentums and the liberal rabbi is Geiger's request in 1836 to the German authorities to establish a Jewish theological faculty at the university: 'Die Gründung einer jüdischtheologischen Facultät, ein dringenden Bedürfniß unserer Zeit' (1836: I8). He argued that rabbinic education should take place in an academic university setting, on the same footing as Christian theological education. Significantly, Geiger named his first scholarly periodical Wissenschaftliche Zeitschrift für jüdische Theologie (Meyer 2004: Io6.). Frankel displays the same tendencies, and his scholarly journal Monatsschrift für Geschichte und Wissenschaft des Judentums (185I-I939) eventually became the most influential academic journal in the German Jewish world, surviving more than eighty years (von der Krone and Thulin 20I3: 275). But when Geiger's request was denied, the alternative of an academic rabbinical seminary was pursued, culminating in the establishment of the Jewish Theological Seminary of Breslau in 1854. Although Geiger was initially slated to be appointed head of the institution, as a result of the recent swing to a more conservative mood in German society, the position went to a moderately liberal rabbi - Zacharias Frankel, Geiger's rival.

\section{Back to the present: participant observations}

I would now like to share some observations on the rabbinical schools from practical, academic and theological perspectives. My focus will be on what I perceive to be tensions, problems and processes that accompany the rabbinical colleges and the school as part of the natural growing pains of young institutions. The Reform and Conservative rabbinical students share some of their practical training and life. This is quite unusual outside Berlin, but since the student body is small, it makes sense to pool resources. The students conduct joint morning worship (shacharit) and sometimes Friday night worship and meal (kabbalat shabbat). Despite some disagreements over religious practice, it works. The differences can be traced back to those that already existed between Geiger and Frankel. Geiger pleaded for the need to liberalise ritual practices, while Frankel thought that it still made sense to preserve the traditional norms. Frankel's judgment 
was based on his view that the majority of Jews were still loyal to these norms. The truth, however, is that this is no longer the case today.

\section{The Talmud}

One current debate among the students and the faculty is over the status of Talmud study. At the School of Jewish Theology, the Talmud is studied on a par with the Bible and Jewish philosophy, for example, in an academic, historical-critical manner. The Zacharias Frankel College, however, argues that the Talmud is the foundation for what they do, and therefore they add mandatory lessons. In response, Geiger students as well have requested and received additional optional lessons, in which the academic method is side-stepped, and the emphasis is on traditional Talmud study. The students told me that they want to be exposed to an unmediated, direct encounter with the text, unencumbered by critical methodologies, which create an obstacle to engendering an existential identification with the 'Tradition'. To my mind this is quite foreign to the character of both schools. The source of this idealised view of the Talmud comes from orthodox yeshivas, where the Talmud is studied in a totally a-historical manner, without any use of the methods derived from the critical-historical method. In the case of the Zacharias Frankel College this is quite ironic, since it was Zacharias Frankel himself who laid the foundation for the critical approach to the study of the Talmud. In his study of the Mishnah (Darkei ha-Mishnah, I859) he showed how to expose the historical layers of the Mishnah, and thus to explain the development of the balakhah.

\section{The Bible}

In the days of Geiger and Frankel, the critical study of the Hebrew Bible/Tanakh was a hot potato for Jewish scholars, tainted with supercessionism, anti-Judaism and antisemitism (see Shavit and Eran 2003; Shavit and Eran 2007; Hacohen 2006). Today, however, biblical criticism is widely practised by Jewish scholars, at the Hebrew University as well as the Jewish Theological Seminary in New York (of Conservative Judaism). Yet, strangely enough, at the joint Geiger-Frankel study sessions devoted to the weekly Torah portion (parashat ha-shavuah), biblical criticism is mostly avoided. Preference is given to medieval commentaries and literary interpretation in the spirit of 'close readings' (as pioneered by the neo-orthodox Bible teacher Nehama Lebowitz).

Similarly, the teaching of the Bible at the School of Jewish Theology seems to be insufficiently invested in applying the critical method, with the result that many students lack knowledge, understanding and appreciation of the contribution that biblical criticism can make to a mature, historical and sophisticated understanding of the Hebrew Bible/ Tanakh. This I have observed both in my classes on rabbinic literature as well as in the sermons delivered by the rabbinical students at the Friday night kabbalat shabbat services. In my courses on rabbinical literature I usually start by teaching a brief introduction to a critical and historical understanding of the Hebrew Bible. Often, I discover that even students who have taken a course or two on the Bible have not learned what the basic insights of Biblical criticism are, in terms of contextualising the Hebrew Bible in the ancient Near East on the one hand, and, on the other, the concept of the successive growth of the Pentateuch as a composite document. I view these insights as necessary foundations for a proper analysis and interpretation of rabbinic literature.

\section{Theology and historicism}

While the historical-critical approach was the accepted highway in the study of culture, religion and theology for most of the nineteenth 
century, towards the end of the century alternatives challenged the hegemony of historical consciousness. Historicism became a problem. Historical research, which had been one of the main pillars of both Geiger's and Frankel's understanding of Judaism, lost its appeal. No wonder that some of our rabbinical students do not share Geiger's and Frankel's historical consciousness. When I taught the historicalcritical perspective on a biblical topic, one student commented, 'I don't believe in historical truth', while another said, 'For Jews, midrash [the homiletical interpretation] is more important than the pshat [the plain, literal meaning]'

The spiritual inspiration for these kinds of sentiments is no longer Geiger or Frankel, but, I propose, Franz Rosenzweig. This GermanJewish philosopher sought to avoid the extremes of naive fundamentalism on the one hand, and simplistic historical criticism on the other. We see this in a comment he made in I922 about the narrative in the Torah where the prophet Balaam's ass suddenly starts talking: 'The ass said to Balaam, "Look, I am the ass that you have been riding all along until this day!"'(Numbers 22:30). Rosenzweig writes: 'All the days of the year, Balaam's talking ass may be a mere fairy tale, but not on the Sabbath wherein this portion is read in the synagogue, when it speaks to me out of the open Torah' (Rosenzweig I955: 123).1

\section{Theology and the secular age}

The academic home of the two rabbinical colleges is called the 'School of Jewish Theology'. However, unlike Christian theology departments, we currently offer no courses aimed at exploring a contemporary theology, also known

1 The German original: 'Alle Tage im Jahr mag mir Bileam's redende Eselin ein Märchen sein; am Sabbat Balak, wenn sie aus die ausgehobene Tora zu mir spricht, nicht' (Rosenzweig, I979: 1004). as systematic theology or constructive theology. Such courses are only now being discussed, and there is a good chance that Jewish systematic theology will soon be taught.

What does theology mean in a secular age? After all, the primary challenge for theology today is the secular world, in which both religious and non-religious people live. It is part and parcel of our languages, practices, values and most basic life orientations. Some of us nevertheless choose to engage in practices that resonate with the vocabulary of religion. These are choices, and not inescapable forms of life, as they formerly were. In Sweden, the historian of religion David Thurfjell published a much-discussed book which began by noting that it is often said that 'Sweden is the world's most secular country' (Thurfjell 2015: I7). He spent the rest of the book problematising this assumption, trying to show that the picture is much more complex. Perhaps the Swedes are not so secular, after all, he argued, since many still practise some vestiges of Christianity. I was not convinced by his thesis (that Sweden is not as secularised as commonly thought), despite the fact that the book provided a sophisticated and fascinating analysis of Swedish attitudes towards religion. For the Jewish people such a shadowy form of religious survival is not sufficient. Jews need a stronger incentive to sustain their identity than, to mention examples from Thurfjell's book, the Swedes who have a family dinner at Easter, or give a child a biblical name. Such an incentive can come from a coherent and meaningful, theological standpoint.

The rabbinical students of the Geiger and Frankel colleges will have to engage with a secular world founded on premises quite different from those which construct the Jewish religious imaginary. The educational challenge is to prepare these future rabbis for the conversation, dialogue and struggle that awaits them.

In the title I refer to the return of the rabbinical seminaries to Berlin. But the Berlin of 
today is not the one that Geiger and Frankel knew, and the rabbinical student of today is very different from those of the past. There is no doubt in my mind that much of our theological discourse needs to be demythologised and our ritual practices stand in dire need of revamping. We live in a world where the horizons for imagining our existence have long ago exploded out of the nineteenth-century frameworkin which Reform and Conservative Judaism took shape, such as progress, history and Enlightenment. There is no escaping deconstructing the classical structures associated with religion. Maybe our very language needs to be re-examined. The foundational role that language plays in shaping our existence is an important theme in German philosophical thought, represented by the names Herder, Heidegger and Gadamer. Today philosophy formulates new questions with regards to what we do when we use language: do our words refer to something real out there, or should we perhaps consider the position of non-realism, also called anti-realism, according to which the truth of a statement is not necessarily dependent upon the correspondence between our words and some external reality? In Sweden this question has been debated among philosophers of religion (see Herrmann 1999; Appelros 2000; Johannesson 2002).

Abraham Geiger and Zacharias Frankel already had a serious difference of opinion over the use of language in worship. At a conference in 1845 Geiger argued that it would be a good idea to use German in some parts of the worship, since many did not understand the Hebrew any more. Frankel disagreed, and insisted on the importance of Hebrew for preserving the tradition. Behind the question of the linguistic translation lurks the question of cultural translation. There comes a point when the beautiful rabbinic Hebrew liturgy composed in late Antiquity, which forms the backbone of the Jewish prayer book (siddur), comes across as foreign and counter-productive for the modern person searching for a language to express their spiritual quest. The prayers invoke a hierarchical cosmos, with divine kingship, angelic choirs and mortal humanity. What the new language of prayer, and of religion in general, should be, is a literary, cultural and theological question that the graduates of the rabbinical seminaries will have to contend with. I look forward to their contributions.

\section{Bibliography}

Appelros,E., 2000. 'Religiös ickerealism och referens till Gud', Svensk kyrkotidning, 8, pp. 72-8.

Geiger, A., 1836, Wissenschaftliche Zeitschrift für jüdische Theologie, $2 / \mathrm{I}$.

HaCohen, Ran, 2006. Reviving the Old Testament: How Wissenschaft des Judentums dealt with High Bible Criticism in Nineteenth-Century Germany (Hebrew) (Tel Aviv, Hakibbutz Hameuchad).

Herrmann, E., 1999. 'Gud, verklighet och den religionsfilosofiska debatten om realism och antirealism', Svensk teologisk kvartalskrift, 75 , pp. 50-63.

Johannesson, K., 2002. Gud för oss. Om den nonmetafysiska realismen och dess konsekvenser för religionsfilosofins uppgift och natur (Stockholm, Bokförlaget Thales).

Krone, K. von der, and Mirjam Thulin, 2013. 'Wissenschaft in context: a research essay on the Wissenschaft des Judentums', Leo Baeck Institute Year Book, 58, pp. 249-8o.

Meyer, M., 2004. 'Two persistent tensions within Wissenschaft des Judentums', Modern Judaism, 24:2, pp. 105-I9.

Rosenzweig, F., 1955. On Jewish Learning (New York, Schocken Books).

— 1979. Briefe und Tagebücher: 2. Band, I9I8-1929 (Dordrecht: Springer).

Shavit, Yaacov, and Mordechai Eran, 2003. The War of the Tablets: The Defense of the Bible in the Nineteenth Century and the Babel-Bibel Controversy, (Hebrew) (Tel-Aviv, Om Oved).

—_ 2007. The Hebrew Bible Reborn: From Holy Scripture to the Book of Books. A History of Biblical Culture and the Battles over the Bible in Modern Judaism (Berlin: de Gruyter)

Thurfjell, D., 20I5. Det gudlösa folket: De postkristna svenskarna och religionen (Farsta: Molin \& Sorgenfrei). 


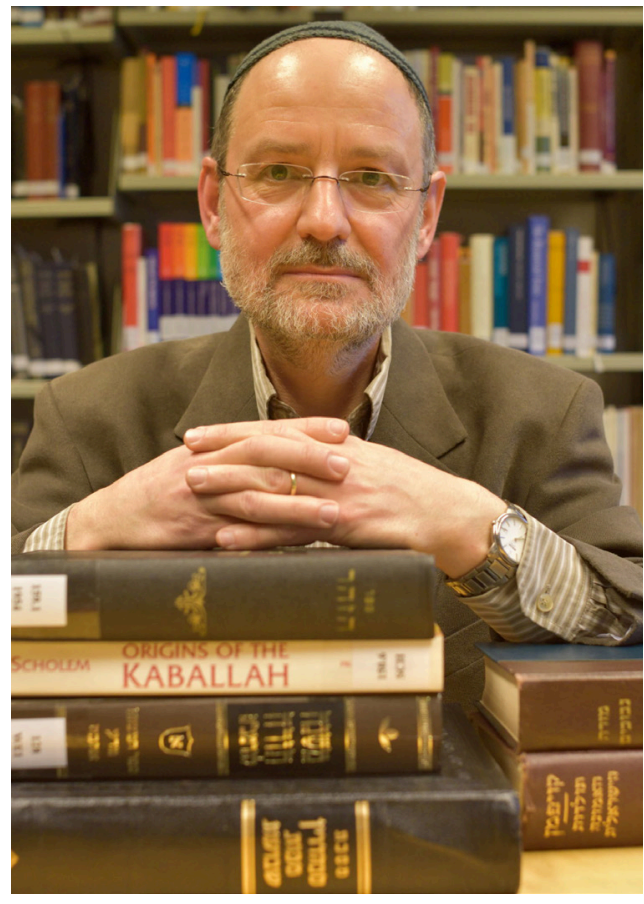

Eli Reich was born in Sweden to Holocaust survivors. He moved to Israel after 9th grade, finished Yeshivah High School, and received his BA at Bar Ilan University in Bible and Jewish philosophy. He did graduate studies at the Jewish Theological Seminary in New York, Hebrew University, Brandeis University, and University of Chicago Divinity School. He received rabbinic ordination (Reform) from Abraham Geiger College, and M A in Jewish Theology from the University of Potsdam. He taught Jewish Studies \& Religious Studies at universities in North America. For the last six years he has taught courses at the School of Jewish Theology, University of Potsdam, Germany, on Bible; Midrash, Mishnah \& Talmud; Liturgy; Maimonides; the Zohar; Nahman of Bratslav \& Rav Kook; Halakhah. Eli also teaches Halakhah at Abraham Geiger College. He is married to Dr Tamar Reich (Hinduism and religious studies) and they have two children, Dr Noa Reich (English literature) and Asaf, a data scientist. 